\title{
Application of a microbial source tracking based on bacterial and chemical markers in headwater and coastal catchments
}

\author{
Jardé Emilie ${ }^{1,{ }^{*}}$, Jeanneau Laurent ${ }^{1}$, Harrault Loïc ${ }^{1}$, Quenot Emmanuelle ${ }^{2}$, Solecki Olivia ${ }^{3}$, \\ Petitjean Patrice ${ }^{1}$, Lozach Solen ${ }^{2}$, Chevé Julien ${ }^{4}$, Gourmelon Michele ${ }^{2}$
}

${ }^{1}$ Geosciences Rennes CNRS UMR6118, Campus de Beaulieu, Bat. 15, 263 avenue du Général Leclerc, 35042 Rennes, France

2 Ifremer, RBE-SG2M-LSEM, Laboratoire Santé Environnement Microbiologie, ZI de la Pointe du

Diable, CS 10070, 29280 Plouzané, France

${ }^{3}$ IRSTEA, UR OPAALE, 17 avenue de Cucillé, CS 64427, 35044 Rennes, France

${ }^{4}$ Ifremer, Laboratoire Environnement Ressources de Bretagne Nord, 38 rue du Port Blanc, BP 70134, 35801 Dinard, France

* Corresponding author : Emilie Jardé, email address : emilie.jarde@univ-rennes1.fr

\begin{abstract}
:
This study identified sources of fecal contamination in three different French headwater and coastal catchments (the Justiçou, Pen an Traon, and La Fresnaye) using a combination of microbial source tracking tools. The tools included bacterial markers (three host-associated Bacteroidales) and chemical markers (six fecal stanols), which were monitored monthly over one or two years in addition to fecal indicator bacteria. 168 of the 240 freshwater and marine water samples had Escherichia coli (E. coli) or enterococci concentrations higher than "excellent" European water quality threshold. In the three catchments, the results suggested that the fecal contamination appeared to be primarily from an animal origin and particularly from a bovine origin in $52 \%$ (Rum2Bac) and $46 \%$ (Bstanol) of the samples and to a lesser extent from a porcine origin in 19\% (Pig2Bac) and $21 \%$ (Pstanol) of the samples. Our results suggested a human fecal contamination in $56 \%$ (HF183) and $32 \%$ (Hstanol) of the samples. Rainfall also impacted the source identification of microbial contamination. In general, these findings could inform effective implementation of microbial source tracking strategies, specifically that the location of sampling points must include variability at the landscape scale.
\end{abstract}




\section{Graphical abstract}

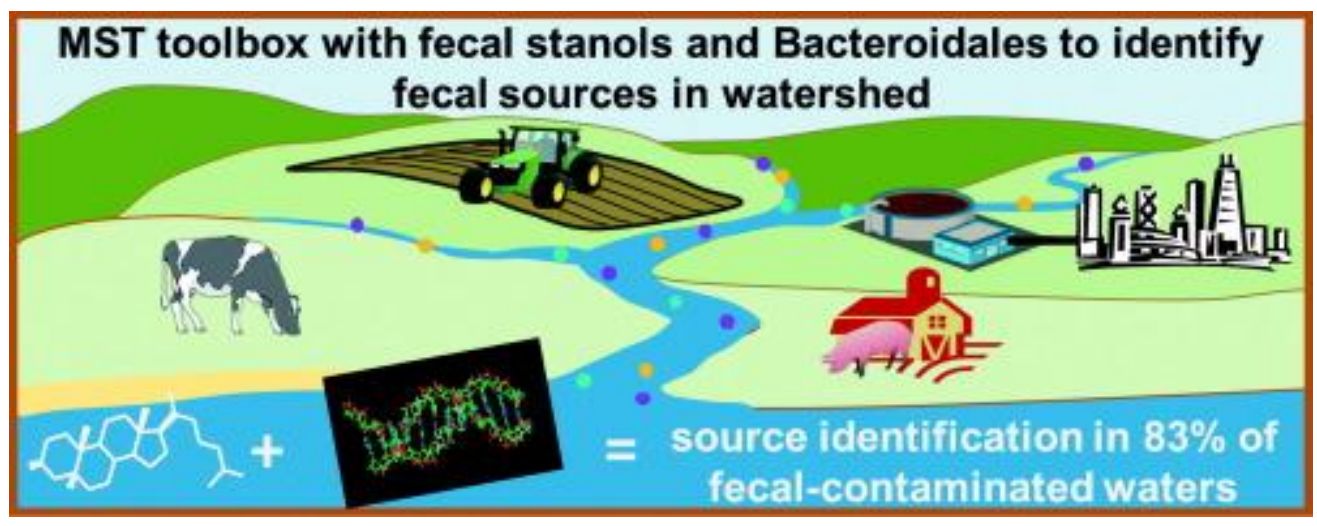

\section{Highlights}

- Test of microbial source tracking in contrasting mixed-use catchments. Monthly monitoring of specific chemical and microbial markers was performed. The toolbox efficiently identified fecal sources in $83 \%$ of the samples. In nested catchments, the number of fecal sources increases downstream. Headwaters and outlets may be integrated for effective management strategies.

Keywords : Fecal contamination, Host-associated, Bacteroidales markers, Fecal stanols, Rainfall, MST toolbox, Mitigation actions 


\section{Introduction}

The microbial quality of coastal environments can be affected by fecal pollution from urban and agricultural sources. Fecal contamination affects waterways worldwide, leading to the closures or downgrading of shellfish-harvesting areas and bathing areas, and to outbreaks of food poisoning through the consumption of contaminated shellfish or waters (Pommepuy et al., 2005). To prevent these sanitary issues, fecal indicator bacteria; often E. coli or enterococci, are used as indicators to determine the level of fecal contamination in water and to classify the water quality as defined by the European regulations (EU 2006/7/EC directive; 
regulation \#854/2004). Different markers have been developed to compliment fecal indicators and allow microbial source tracking toolbox (MST toolbox) (Field and Samadpour, 2007). Specifically, these chemical and microbial markers distinguish fecal pollution sources, i.e. human, bovine, porcine, etc. (Boehm et al., 2003; Rusinol et al., 2016; Sidhu et al., 2013; Tran et al., 2015).

As highlighted by Tran et al. (2015), a suitable MST toolbox needs to be customized to the study area, including characteristics such as anthropogenic activities and land use patterns. In Brittany (northwestern France), the most widespread agricultural activity is intensive livestock, primarily cows and pigs. For this area, it is therefore necessary to distinguish between human, bovine, and porcine sources of fecal contamination. A suitable MST toolbox using microbial and chemical markers has been previously developed for the specific context in Brittany by Gourmelon et al. (2010). This toolbox combines three host-associated real-time PCR Bacteroidales markers designed to identify human (HF183), ruminant (bovine and ovine; Rum2Bac), and porcine (Pig2Bac) fecal contamination (Bernhard and Field, 2000; Mieszkin et al., 2009; Mieszkin et al., 2010; Seunrick et al., 2005) as well as fecal stanols, chemical markers whose distribution can be used to distinguish between human, porcine, and bovine sources of fecal contamination (Derrien et al., 2011; Derrien et al., 2015; Leeming et al., 1996). Real-time PCR markers have been found to offer high sensitivity and specificity, in this French region, ranging from $78 \%$ to $100 \%$ (Mauffret et al., 2012). A sensitivity of $78 \%, 98 \%$ and $100 \%$ was obtained for HF183, Rum2Bac and Pig2Bac, respectively. The lower sensitivity of HF183 was due to the few positive human feces samples whereas all the WWTP effluents tested were found positive. A specificity of $99 \%$, 94\%, and $99 \%$ was obtained for HF183, Rum2Bac and Pig2Bac, respectively. Furthermore, these markers were found highly sensitive and specific in other countries. The review of 32 studies focusing on the HF183 marker by Ahmed and co-workers in 2016 (Ahmed et al., 2016) show an overall host sensitivity and specificity of $83.1 \% \quad(n=1242$ targeted fecal samples analysed) and $94.6 \%$ ( $n=2966$ non targeted fecal samples tested). In addition, 
Pig2Bac marker was also found highly specific in USA and Israel and Rum2Bac in USA (Raith et al., 2013; Heaney et al., 2015; Ohad et al., 2015).

In Europe, shellfish-harvesting areas and bathing areas are classified according to the fecal indicator bacteria level in shellfish (E. coli) and water (E. coli and enterococci; EU 2006/7/EC directive; regulation \#854/2004). With regards to bathing areas, fecal indicator bacteria are used to monitor and classify bathing waters as insufficient, good, or excellent (threshold values in Table S1). Furthermore, a water bathing profile has to be established in all the European bathing areas, identifying the potential sources of fecal contamination (2006/7/EC directive).

There is therefore a need for tools to efficiently identify sources of fecal contamination in waters that do not comply with European water quality guidelines.

In this study, we used a MST toolbox based on bacterial and chemical markers at the catchment scale to study seasonal variations in term of intensity and sources of fecal contamination in three contrasting catchments in Brittany, France. We hypothesized that the use of a MST toolbox at a monthly frequency, in concert with precipitation data, should allow the determination of the main seasonal fecal contamination sources depending on the catchment land use and land cover. These results could help local stakeholders to improve land use management by decreasing microbial contamination threats.

\section{Material and methods}

2.1. Catchment characteristics and water sampling strategy

2.1.1. Justiçou, Pen an Traon and La Fresnaye catchments.

The Justiçou catchment (catchment J; 2,064 inhabitants; $9 \mathrm{~km}$ long; $5.6 \mathrm{~km}^{2}$ ) is located in the upstream part of the Elorn catchment (Figure 1, S1). The catchment of the Elorn estuary (Brittany, France) covers $385 \mathrm{~km}^{2}$ and is located to the north-east of the Bay of Brest. A detailed description of this catchment can be found in Mieszkin et al. (2013). Fecal bacteria 
sources in the catchment $\mathrm{J}$ include one wastewater treatment plant located at Plouneventer (WWTP; 1,298 inhabitants-equivalents, extended aeration activated sludge process, located just upstream of the $\mathrm{J} 1$ sampling point) pig, cattle, and poultry breeding (animal and human densities are shown in Figure S1), manure spreading, and livestock grazing area. Five sampling points ( $\mathrm{J} 1$ to $\mathrm{J} 5)$ were selected in order to include the impact of the WWTP on a small stream with pressure from intensive agriculture (Table S2, Figure 1).

The Pen an Traon catchment (catchment P; 629 inhabitants) is a coastal catchment, which covers $3.7 \mathrm{~km}^{2}$ and includes a swimming area (Pen an Traon beach, P5) (Figures 1, S2). Catchment $P$ is divided into two areas that drain two streams flowing into the Pen an Traon beach: (i) the Poul ar Vilin stream (1.2 km; $1.2 \mathrm{~km}^{2} ; \mathrm{P} 1$ and P2) flows along a rural area mainly dominated by pastures and livestock, and (ii) the Pouldu stream (1.3 km; 1 km²; P3 and P4) flows along two small urban areas without a municipal WWTP and including pastures (Figure S2). In a recent swimming-water profile study (Patris and Perenne, 2011), these two streams were identified as potential contributors (4\% of the E. coli fluxes in the Elorn estuary) to fecal contamination inputs. The high E. coli concentration and their proximity to the swimming beach increase risk of contamination. Five sampling points were monitored upstream and downstream from the Poul ar Vilin (P1 and P2) and Pouldu streams (P3 and P4) and at the Pen an Traon beach (P5, Table S2). These two headwater catchments were chosen to evaluate point and non-point fecal contamination sources.

The La Fresnaye catchment (catchment F; $121 \mathrm{~km}^{2} ; 6,923$ inhabitants) is located in the northeastern part of Brittany (Figures 1, S3). Catchment $F$ is divided into four subcatchments: Fremur (river length $=50 \mathrm{~km}$, area $=77.4 \mathrm{~km}^{2}, \mathrm{~F} 1$ ), le Rat (river length $=10.5 \mathrm{~km}$, area $=19.2 \mathrm{~km}^{2}, \mathrm{~F} 2$ ), le Clos (river length $=8.7 \mathrm{~km}$, area $=13.3 \mathrm{~km}^{2}, \mathrm{~F} 3$ ), and Kermiton (river length $=2.3 \mathrm{~km}$, area=6.3 $\left.\mathrm{km}^{2}, \mathrm{~F} 4\right)$. The catchment includes 12 towns with seven WWTPs: two activated sludge WWTPs, three lagoon-based WWTPs, two reed bed filter WWTPs, and one using rotating biological contactors dimensioned for 250 to 16,000 inhabitantsequivalents). Catchment $\mathrm{F}$ has intensive livestock production (Figure S3). Sampling points were monitored at the outlet of each sub-catchment (F1: Fremur; F2: Le Rat; F3: Le Clos; 
F4: Kermiton) and in the seawater (F5), which was always sampled at high tide, downstream of the outlet of the Kermiton stream (F4).

\subsubsection{Water sampling strategy}

Monthly monitoring was performed over a one-year period in the catchments $\mathrm{J}$ and $\mathrm{P}$ (from August $23^{\text {rd }}, 2010$ to July $17^{\text {th }}, 2011$ ) and over a two-year period in the catchment $F$ (from February $25^{\text {th }}, 2013$ to January $\left.5^{\text {th }}, 2015\right)$. Water samples were collected from the surface (top $10-\mathrm{cm}$ ) using sterilized bottles and were immediately placed in an ice chest, where they were kept until analysis. All samples were filtered in the laboratories within one day of sampling.

\subsection{Water sample analysis}

\subsubsection{Enumeration of fecal indicator bacteria}

Escherichia coli and enterococci were counted using microplate methods (EN ISO 9308-3 [Anonym. 1999a] and EN ISO 7899-1 [Anonym. 1999b]), respectively, with a detection limit of the 15 most probable number (MPN) per $100 \mathrm{~mL}$ of water sample.

\subsubsection{Host-associated Bacteroidales marker analysis}

Water samples $(1 \mathrm{~L})$ were either filtered under sterile conditions through $0.45 \mu \mathrm{m}$ nitrocellulose membranes (Pall Gelman GN-6 Metricel; Pall Corporation) or centrifuged for highly turbid samples. DNA was extracted using the Fast DNA for soil kit (MP Biomedical) and DNA extracts were eluted in $100 \mu$ I DNA Elution Solution-Ultra Pure Water and stored at $-80^{\circ} \mathrm{C}$ until PCR analysis. Host-associated Bacteroidales markers were quantified by realtime PCR as previously reported by Mauffret et al. (2012) and using the primers and probes described by Seurinck et al. (2005): HF183 and Mieszkin et al. (2009-2010): Pig2Bac and Rum2Bac. The procedure is described in detail in the supplementary information.

\subsubsection{Fecal stanol analysis}


Fecal stanols were extracted from filtered $(0.7 \mu \mathrm{m}$ glass-fiber) water samples $(1 \mathrm{~L})$ by solid phase extraction and quantified by gas chromatography coupled to mass spectrometry using an internal calibration as described by Jeanneau et al. (2011). The procedure is described in detail in the supplementary information.

\subsection{Climatic and chemophysical parameters}

Rainfall data (1-day cumulative rainfall) were provided by the meteorological stations from Meteo France at Guipavas $\left(48^{\circ} 25^{\prime} 59.99 " \mathrm{~N}\right.$; $-4^{\circ} 24^{\prime} \mathrm{O}^{\prime \prime} \mathrm{W}$ - catchments $\mathrm{J}$ and $\left.\mathrm{P}\right)$ and Pleurtuit (48॰34'59.98"N; -24'0.01"W - catchment F).

Water temperature $\left({ }^{\circ} \mathrm{C}\right)$ and dissolved oxygen $(\mathrm{mg} / \mathrm{L})$ were measured using a multi sensor probe 3430 (WTW) equipped with a FDO 925 electrode, and Tetracon 925 electrode on nonfiltered water samples. Turbidity (NTU) was measured at the laboratory using an $\mathrm{HACH}$ $2100 \mathrm{~N}$ turbidimeter.

A specific focus on the effect of rainfall intensity on FIB or fecal marker levels or their presence in the water samples was performed. Samples were grouped into three classes of rainfall intensity: no rain, rainfall intensity $<10 \mathrm{~mm}$, and rainfall intensity $\geq 10 \mathrm{~mm}$ (1-day cumulative rainfall).

\subsection{Statistical analyses}

All statistics were performed using XLSTAT 2013, Addinsoft. Non-parametric Kruskal-Wallis tests were performed with Dunn's multiple comparison tests as a post-hoc test with a 99\% confidence level $(\alpha=0.01)$. Spearman correlations $(\alpha=0.01)$ were performed to test for significant correlations between chemophysical or climatic parameters and fecal indicators or fecal markers.

The stanol fingerprints of the water samples were investigated using the PCA model developed by Derrien et al. (2012) to differentiate between human, porcine, and bovine sources of fecal contamination. With this model, fecal stanols can be used to identify human 
(Hstanol), bovine (Bstanol) and/or porcine (Pstanol) fecal contamination. The procedure is described in detail in the supplementary information.

The results (source assignment with host-associated Bacteroidales markers and fecal stanols) were ranked in four classes from $A$ to $D$ :

A: both markers gave the same source assignment (either a single source or a combination of two or three sources).

B: one marker gave a source assignment (either a single source or a combination of two or three sources) and the other did not provide a source assignment.

C: both kinds of markers gave different source assignments (no common source identified by host-associated Bacteroidales and fecal stanols).

D: no markers were quantified or detected.

\section{Results and Discussion}

3.1. Overview of fecal contamination levels in the catchments.

Escherichia coli and enterococci were quantified in respectively $97 \%$ and $80 \%$ of the 240 water samples (Table S3). E. coli levels exceeded the European "excellent" water quality guideline values for inland and marine waters $\left(\geq 2.7 \log _{10}\right.$ MPN/100 mL and $\geq 2.4 \log _{10}$ MPN/100 mL, respectively) in $71 \%$ of the rivers and $47 \%$ of the marine waters. Enterococci levels exceeded the threshold for the "excellent" classification (according to the 2006/7/CE directive) for inland and marine waters ( $\geq 2.3 \log _{10} \mathrm{MPN} / 100 \mathrm{~mL}$ and $\geq 2 \log _{10} \mathrm{MPN} / 100 \mathrm{~mL}$, respectively) in $50 \%$ of the rivers and $28 \%$ of the marine waters.

In catchments $\mathrm{J}, \mathrm{P}$, and $\mathrm{F}, \mathrm{E}$. coli was quantified in $100 \%, 92 \%$, and $98 \%$ of the waters, respectively. The $E$. coli levels ranged from 1.6 to $5.8 \log _{10} \mathrm{MPN} / 100 \mathrm{~mL}$ in catchment J, from 1.2 to $4.8 \log _{10}$ MPN /100 mL in catchment $P$, and from $1.2 \log _{10} \mathrm{MPN} / 100 \mathrm{~mL}$ to $5.3 \log _{10}$ MPN/100 $\mathrm{mL}$ in catchment F. (Figure 2 and Table S3). In catchments $\mathrm{J}, \mathrm{P}$, and $\mathrm{F}$, enterococci were quantified in $88 \%, 70 \%$, and $82 \%$ of the waters, respectively. The enterococci levels ranged from 1.6 to $6.4 \log _{10} \mathrm{MPN} / 100 \mathrm{~mL}$ in-catchment $\mathrm{J}$, from 1.2 to 4.5 
$\log _{10}$ MPN /100 mL in catchment $P$, and from $1.2 \log _{10}$ MPN/100 mL to $4.8 \log _{10}$ MPN/100 mL in catchment $\mathrm{F}$ (Figure 2 and Table S3). In catchment J, E. coli and enterococci levels were especially high at point $\mathrm{J} 1$ (from 3.2 to $5.8 \log _{10} \mathrm{MPN} / 100 \mathrm{~mL}$ for $E$. coli concentrations and from 2.5 to $5.4 \log _{10}$ MPN/100 mL for enterococci concentrations) compared to J2 to J5 (Figure 2). J1 is located downstream of the WWTP effluent (Table S2). In catchment P, no significant difference between the sampling points was observed. In catchment $F$, the $E$. coli concentrations were significantly lower in marine waters (F5) than in river waters (F1 to F4, Figure 2). The E. coli levels exceeded the "excellent" threshold in $83 \%, 50 \%$, and $73 \%$ of the river samples from the catchments $\mathrm{J}, \mathrm{P}$, and F, respectively. Marine waters exceeded the "excellent" E. coli threshold in $33 \%$ of the samples in catchment $\mathrm{P}$ and $54 \%$ in catchment $\mathrm{F}$. The enterococci levels exceeded the "excellent" threshold in $57 \%, 42 \%$, and $50 \%$ of the river samples from the $\mathrm{J}, \mathrm{P}$ and $\mathrm{F}$ catchments, respectively. Marine waters exceeded the "excellent" E. coli threshold in $33 \%$ of the samples in catchment $\mathrm{P}$ and $25 \%$ in catchment $\mathrm{F}$.

\subsection{Reliability of the MST toolbox.}

The reliability of the MST toolbox based on host-associated Bacteroidales markers and fecal stanols was evaluated on the 168 of 240 samples that exceeded the "excellent" threshold (see threshold values in Table S1).

Evaluation of the toolbox was based on the ability to consistently identify the origins of fecal contamination as determined by host-associated Bacteroidales and fecal stanols.

$54 \%$ of samples fell into class A (both kinds of markers gave the same source assignment), $29 \%$ in class $B$ (one kind of marker gave a source assignment), $10 \%$ in class $\mathrm{C}$ (both kinds of markers gave different sources), and $8 \%$ in class D (no markers were quantified or detected). The MST toolbox was considered efficient in $83 \%$ of the samples ( $A+B$ classes).

The differences in source assignments between the two kinds of markers observed for the class B and C samples could be due to differential persistence of fecal stanols and hostassociated Bacteroidales markers in surface water (Jeanneau et al., 2012; Solecki et al., 2011). For example, for 11 of the 17 class $C$ samples, fecal stanols assigned a porcine 
origin, whereas host-associated Bacteroidales assigned a bovine and/or human origin. Pig slurry storage lead to a decrease in the Pig2Bac detection rates (Mieszkin et al., 2009) and Pig2Bac has a lower persistence time $\left(T_{90}=1.9\right.$ days $)$ than the porcine stanol fingerprint $\left(T_{90}\right.$ between 29.1 and 32.0 days, Solecki et al., 2011). Consequently, it would be preferable not to use those results in terms of catchment management, and to perform further investigations on those sampling points.

All class $D$ samples were collected in catchments $F$ (seven marine waters from $F 5$ and three inland waters from F4) and P (two marine waters from P5 and one inland water from P4) with E. coli levels ranging from 2.4 (F5 on December $2^{\text {nd }}, 2013$ ) to $4.3 \log _{10} \mathrm{MPN} / 100 \mathrm{~mL}$ (F4 on September $8^{\text {th }}, 2014$ ), and enterococci levels ranging from $1.2 \log _{10}$ MPN/100 mL (F5 on October $6^{\text {th }}$, 2014) to $3.1 \log _{10} \mathrm{MPN} / 100 \mathrm{~mL}$ (F4 on October $7^{\text {th }}, 2013$ ). Dilution, sedimentation with particles and/or additional fecal sources (birds, wild animals, etc.) might explain the lack of fecal source assignment.

To assess the reliability of the MST toolbox in less contaminated waters, we also included the 72 samples with $E$. coli or enterococci levels below the "excellent" water quality guideline values. Classes A, B, C, and D represented $51 \%, 30 \%, 9 \%$, and $10 \%$ of the samples, respectively. The reliability of the MST toolbox remains unchanged with a clear source assignment for $81 \%$ of the samples.

\subsection{Dynamics of fecal contamination at the landscape scale.}

Throughout the three catchments, the results suggested that the main fecal contamination was from an animal origin, and primarily bovine in 52\% (Rum2Bac) and 46\% (Bstanol) of the samples, and secondarily porcine, in 19\% (Pig2Bac) and 21\% (Pstanol) of the samples. The results suggested a human fecal contamination in 56\% (HF183) and 32\% (Hstanol) of the samples (Table S3). HF183 (56\%) was more prevalent than Hstanol (32\%) in the 168 water samples. In 25 of the samples with HF183 and no human stanol fingerprint, stanols indicated an animal fecal contamination source whereas host-associated Bacteroidales indicated a mixture of animal and human contamination. In 8 samples, only HF183 was quantified, and 
stanols indicated fecal contamination from animal origin. In the last 14 samples, stanols were not detected. One explanation for these patterns is differential persistence of fecal stanols and host-associated Bacteroidales markers in surface water. However, a previous microcosm study (Jeanneau et al., 2012) suggested a longer persistence time for human stanol fingerprint ( $T_{50}$ between 3.8 and 5.4 days, Jeanneau et al., 2012) than for HF183 ( $T_{90}=1.7$ days). Fecal stanols are mainly used to track human fecal contamination from WWTP. It has been demonstrated that the intensity of the cholesterol-to-coprostanol conversion in the intestine is highly variable among humans (Gerard, 2014), which could lead to a lack of sensitivity of fecal stanol to track individual septic systems. The difference in the identification of human fecal contamination with host-associated Bacteroidales and fecal stanols strengthens the need to use MST toolbox based on several markers to identify the fecal sources at the catchment scale.

Besides fecal contamination from animal origin, human contamination remained important at the catchment scale and remained a problem in terms of risk assessment because human health risk appears to be substantially higher in waters impacted by human sources compared to animal sources such as sea birds, poultry or pigs (Soller et al., 2010). One explanation for this is the host-specific nature of viruses such as noroviruses which are the most frequently identified pathogen in shellfish outbreaks (Campos and Lees, 2014; Le Guyader et al, 2013).

\subsubsection{Spatial variability}

Figure 3 presents the frequency of detection of human, bovine, and porcine markers (hostassociated Bacteroidales and/or fecal stanols) at the different sampling points in the three catchments.

In catchment $\mathrm{J}$, host-associated markers were mainly from human (92\% of the samples) and bovine ( $62 \%$ of the samples) fecal contamination. Only bovine markers were quantified at J2, the upstream sampling point for-catchment $\mathrm{J}$. The prevalence of human markers in this catchment is likely due to the WWTP located just upstream $\mathrm{J1}$, which degrades water quality 
through point $\mathrm{J} 5$ (the downstream station in this catchment). Porcine markers (24\% of the samples) were quantified at J3 (50\%), J4 (33\%) and J5 (18\%), corresponding to porcine density in this area (around $2091 \pm 207 \mathrm{pig} / \mathrm{km}^{2}$; Table S2 and Figure S1).

Catchment $P$ is a small headwater catchment mainly characterized by pastures and livestock (a bovine density range from 102 to 121 cattle $/ \mathrm{km}^{2}$, Table S2 and Figure S2). Fecal contamination was mainly from bovine sources (63\% of the samples). The occurrence of exclusively bovine markers at the upstream sampling points (P2 and P4) is in line with the cattle density and land use. Human markers (50\% of the samples) only occurred downstream (P1 and P3) following human density (40 and 328 inhabitants $/ \mathrm{km}^{2}$, respectively, Table S2 and Figure S2). At P5, the beach sampling point, the fecal contamination came from all three sources studied here (human, bovine, and porcine).

Bovine ( $81 \%$ of the samples), human ( $45 \%$ of the samples), and porcine markers $(42 \%$ of the samples) were quantified in all of the sampling points from catchment $F$. This catchment is also characterized by the highest frequency of detection of pig markers ( $42 \%$ of the samples) compared to catchment $\mathrm{J}$ (24\% of the samples) and $\mathrm{P}$ (6\% of the samples), while the pig density is three times lower in catchment $\mathrm{F}$ than in catchment $\mathrm{J}$. This lack of relationship between pig density and the occurrence of pig markers might be due to the management practice of spreading pig slurry which is subject to a regional spreading schedule and can be carried out both inside and outside the catchment.

At the landscape scale, the spatial variability highlights that headwater catchments are mainly impacted by one source of microbial contamination; however as one moves downstream, this specificity is lost due to a combination of sources. Both scales are important to improve management strategies, especially in nested catchments. While large catchments can be used to identify the main sources, the headwater catchment scale is the operational size to develop management strategies. 
3.3.2. Impact of climatic and chemophysical parameters on fecal indicator bacteria and markers.

Water turbidity and rainfall can have an effect on fecal matter diffusion from soils to water through soil leaching and feces degradation (Villemur et al., 2015). Among the different monitored climatic and chemophysical parameters (water temperature, dissolved oxygen, turbidity and rainfall, Table S4), rainfall was most strongly correlated ( $p$-value $<0.0001$ to $p$ value $<0.001$ ) with fecal indicator bacteria ( $p$-value $<0.0001, r=0.33$ and 0.34 with $E$. coli and enterococci, respectively) and fecal human markers $(p<0.0001, r=0.46,0.36$ and 0.26 with Rum2Bac, Pig2Bac and Pstanol, respectively). Turbidity was very weakly correlated with fecal indicator bacteria ( $\mathrm{p}$-value $<0.01, r=0.09$ and 0.12 with $E$. coli and enterococci, respectively) and weakly with HF183 ( $p$-value $<0.01, r=0.104)$. Turbidity and rainfall were significantly correlated ( $p$-value $<0.0001, r=0.39$ ), as expected Moatar et al. (2017).

The mean and maximum cumulative 1-day rainfall values were more than two times higher in the $\mathrm{J}$ and $\mathrm{P}$ catchments than in catchment $\mathrm{F}$ (Table 1). In catchments $\mathrm{J}$ and $\mathrm{P}$, the daily rainfall was higher than $10 \mathrm{~mm}$ (Table S3) on three sampling dates (August 2010, January 2011, February 2011), in catchment $F$ the rainfall was higher than $10 \mathrm{~mm}$ on three sampling dates over the two year period (March 2013, November 2013 and 2014). Heavy rainfall (more than $20 \mathrm{~mm}$ per day in Brittany; Dubreuil et al., 1996) only occurred on three sampling dates in the three catchments, in August 2010 and February 2011 in catchments $\mathrm{J}$ and $\mathrm{P}$ and in March 2013 in catchment $\mathrm{F}$. Among the 168 samples (50 at J, 32 at $\mathrm{P}$ and 86 at $\mathrm{F}$ ) with $E$. coli or enterococci concentrations exceeding the "excellent" water guideline value, samples collected during wet periods (with rainfall $\geq 10 \mathrm{~mm}$ per day) represented $26 \%$ at $\mathrm{J}, 25 \%$ at $P$, and $17 \%$ at $F$. In the three catchments, there were more samples (56\% at J, 53\% at $\mathrm{P}$, and $29 \%$ at $F$ ) with high E. coli concentrations that were collected during dry periods (no rain before sampling). Figure 4 represents the $E$. coli concentrations $\left(\log _{10} \mathrm{MPN} / 100 \mathrm{~mL}\right.$ ) by cumulative amount of rainfall $(\mathrm{mm})$ during one day prior to sampling at the three catchments for samples with proven fecal contamination. 
Rainfall had contrasting effects on the $E$. coli concentrations in catchments $\mathrm{J}, \mathrm{P}$, and $\mathrm{F}$. In catchment $\mathrm{J}$, the highest, average and lowest $E$. coli concentrations were quite similar irrespective of the rainfall intensity (no significant difference according to the rainfall intensity has been recorded). In catchment $\mathrm{P}$, the $E$. coli concentrations increased with low rain intensity $(0<$ rain $<10 \mathrm{~mm})$ and remain stable when the rainfall intensity was over $10 \mathrm{~mm}$. In catchment $\mathrm{F}$, the highest, average and lowest $E$. coli concentrations continuously increased with increasing rain intensity $(p$-value $=0.004$ between the dry and wet periods in catchment $F)$, but were significantly lower overall than in catchment $J(p$-value $=0.001)$. These different rainfall effects in the three catchments could be due to different sampling times since rainfallrunoff increases the $E$. coli concentration for a very short time period (2-3 hours depending on the size of the catchment; Bougeard et al., 2011). Samples were not always taken in the three catchments over this short period of time. Several authors have studied the effect of rainfall on fecal indicator bacteria concentrations and showed that rainfall is deemed to be one of the most important hydrological factors affecting the transport of fecal indicator bacteria in the environment (Heaney et al., 2015; Tran et al., 2015). However, as already mentioned in Tran et al. (2015), the impacts of rainfall and the previous dry period on fecal indicator bacteria showed conflicting results that strongly depended on both the geographical area and studied catchment which are; difficult to quantify (Liang et al., 2015). Moreover, as demonstrated by Muirhead et al. (2005), the majority of the E. coli originating from fecal sources can withstand leaching during rainfall events and be released later (Muirhead and Monogan, 2012). This observation suggests that $E$. coli leaching should be considered as a diffusive pollution event instead of a point source.

The detection frequency of bovine markers increased with rainfall in the three catchments (Figure 5). Muirhead and Monogan (2012) identified rainfall runoff as the primary pathway for fecal losses from agricultural catchments with dairy livestock activities. Moreover, a positive correlation between 1-day rainfall and ruminant-associated Bacteroidales markers (Rum2Bac) was observed here ( $p$-value $<0.0001, r=0.46$, Table S4) and in another French 
catchment (Mauffret et al., 2012). In catchments $\mathrm{J}$ and $\mathrm{F}$, this increase was effective for rainfall $\geq 10 \mathrm{~mm}$, while in catchment $\mathrm{P}, \mathrm{a}<10 \mathrm{~mm}$ rainfall was sufficient enough to produce this result. These different relationships can result from catchment topography, which controls surface runoff (Collins et al., 2005; Rusinol et al., 2016). In catchment $P$, the average slope (Figure S3) is $4.5 \%$, which is two to three times higher than in catchments $\mathrm{J}$ and F. In Brittany, bovine cattle are primarily reared outdoors on grass with a direct input of fecal matter. Consequently, runoff from grazing fields is an important export mechanism for bovine fecal contamination (Muirhead and Monogan, 2012).

The relationship between rainfall and the detection frequency of human markers was also catchment dependent. In catchments $\mathrm{P}$ and $\mathrm{F}$, the detection frequency of human markers increased for rainfall $\geq 10 \mathrm{~mm}$. These increases could be due to exceedance of the waste water treatment capacity of collective plants and/or individual septic systems (Rusinol et al., 2016). Conversely, in catchment $\mathrm{J}$, the detection frequency of human markers decreased from $96 \%$ to $77 \%$ with increasing rainfall intensity. This could be due to a dilution effect of the WWTP input located upstream $\mathrm{J} 1$.

Similarly to the detection of human markers, the relationship between rainfall and the detection frequency of pig markers was catchment dependent. In catchment $\mathrm{J}$, it decreased from $25 \%$ to $15 \%$ when the rainfall intensity increased. In catchment $\mathrm{P}$, pig markers were only detected at P5, which is the beach point influenced by inputs from outside the catchment $P$ and for rainfall $\geq 10 \mathrm{~mm}$. In catchment $F$, the detection frequency of pig markers remained stable (from $36 \%$ to $39 \%$ ) for rainfall $<10 \mathrm{~mm}$ and increased to $53 \%$ for rainfall $\geq$ $10 \mathrm{~mm}$. In catchment $\mathrm{J}$, pig markers seem to be diluted by rainfall, which could indicate a chronic point source contamination that is similar, but with a lower impact, to a WWTP effluent impact. In catchments $\mathrm{P}$ and $\mathrm{F}$, the detection frequency of pig markers increased with rainfall $>10 \mathrm{~mm}$, which probably results from runoff from agricultural areas enriched with pig slurry. 
To summarize, in catchment $\mathrm{J}$, a small urban headwater catchment $\left(5.6 \mathrm{~km}^{2}\right)$, rainfall did not modify $E$. coli concentrations, which are mainly controlled by the continuous discharge from a WWTP. In catchment $\mathrm{P}$, a rural headwater catchment $\left(3.7 \mathrm{~km}^{2}\right)$ dominated by livestock, moderate rainfall $(<10 \mathrm{~mm})$ induced an increase in the $E$. coli concentrations mainly through the mobilization of cow feces during heavy rainfall $(\geq 10 \mathrm{~mm})$ and individual human septic systems could be also mobilized. In catchment $F$, a larger catchment $\left(116 \mathrm{~km}^{2}\right)$, the $E$. coli concentration trends was controlled by the rain intensity. Moderate rainfall $(<10 \mathrm{~mm})$ induced a moderate increase in the $E$. coli concentrations mainly due to runoff from cattle grazing areas located close to the streams. Heavy rainfall $(\geq 10 \mathrm{~mm})$ induced a significant increase in the $E$. coli concentrations due to runoff from cattle grazing areas, agricultural areas enriched with pig slurry, and an exceedance of the WWTP capacity of collective plants and/or individual septic systems.

\section{Conclusion}

In the three monitored catchments, fecal contamination was mainly from a bovine origin. As the cattle primarily graze in outdoor pastures, feces may be leached by rainfall leading to export to streams throughout the season, acting as a diffusive contaminant source.

As stated by Collins (2004) and Rusinol et al (2016), a way to prevent this diffusive fecal contamination from cattle could be to physically exclude or at least to limit exchanges between grazing pastures from rivers via the implementation of fences around grazed meadows, for example.

Fecal contamination from humans was also significant in the three catchments. This is particularly concerning since the health risks associated with exposure to waters impacted by human fecal sources are more harmful than waters contaminated by animal sources (Soller et al., 2010). The management of stormwater overflows and the effective sizing of WWTPs could be reliable mitigation actions to limit human fecal contamination at the catchment scale (McLellan et al., 2007). 
In conclusion:

- The quantification of fecal indicator bacteria is prerequisite for all studies dealing with fecal contamination.

- The association of both bacterial and chemical markers is highly efficient to identify the main source of fecal contamination in water samples $(83 \%$ of the samples in this study).

- At the catchment scale, the sampling strategy has to be carefully planned to include catchment characteristics such as hydrology, topography, and the known potential sources of contaminations (farms, WWTPs etc.). For example, the sources of fecal contamination in the headwaters of a catchment are mainly driven by single sources whereas at the outlet, sources of fecal contamination are less species-specific due to source mixing.

- Rainfall is the most significant environmental parameter driving the transfer of fecal contamination from soil to streams.

\section{Acknowledgements}

This work has been partially funded by the Fond Unique Interministeriel, Regional council of Brittany, County council of Morbihan, County council of Finistère and Brest Métropole Océane by (Marquopoleau project) and by the European Regional Development Fund Interreg IVa program (Riskmanche project). We thank C. Marin and C. Hubert from Ifremer and E. Guillerm from Labocea for their technical support. We are especially grateful for the assistance of local stakeholders for their permission to take samples and to share catchment characteristic data. Dr. Benjamin W. Abbott and Dr. S. Mullin post-edited the English style (www.trad8.eu/us/sara-mullin.html).

\section{References}

Anonymous, 1999a. NF EN ISO 9308-3: water quality. Detection and enumeration of Escherichia coli and coliform bacteria in surface and waste water. Miniaturized method (most probable number) by inoculation in liquid medium. International Organization for Standardization, Geneva, Switzerland. 
Anonymous, 1999b. NF EN ISO 7899-1: water quality. Detection and enumeration of intestinal enterococci in surface and waste water. Miniaturized method (most probable number) by inoculation in liquid medium. International Organization for Standardization, Geneva, Switzerland.

Ahmed, W., Hughes B., Harwood V.J., 2016. Current status of marker genes of Bacteroides and related taxa for identifying sewage pollution in environmental waters. Water 2016, 8, 231-258. doi:10.3390/w8060231.

Bernhard, A.E., Field, K.G., 2000. A PCR assay to discriminate human and ruminant feces on the basis of host differences in Bacteroides-Prevotella genes encoding 16S rRNA. Applied Environmental Microbiology 66, 4571-4574. doi: 10.1128/AEM.66.10.45714574.2000

Boehm, A.B., Fuhrman, J.A., Mrse, R.D., Grant, S.B., 2003. Tiered approach for identification of a human fecal pollution source at a recreational beach: case study at Avalon Bay, Catalina Island, California. Environmental Science \& Technology 37, 673-680. doi: 10.1021/es025934x

Bougeard, M., Le Saux, J-C., Pérenne, N., Baffaut, C., Robin, M., Pommepuy, M., 2011. Modeling of Escherichia coli fluxes on a catchment and the impact on coastal water and shellfish quality. Journal of the American Water Resources Association 47, 350-366. doi: 10.1111/j.1752-1688.2010.00520.x

Campos, J.-A., Lees, D.N., 2014. Environmental transmission of human noroviruses in shellfish waters. Applied Environmental Microbiology 80, 3552-3561. Doi: 10.1128/AEM.04188-13

Collins, R., 2004. Fecal contamination of pastoral wetlands. Journal of Environmental Quality, 33, 1912-1918. doi: 10.2134/jeq2004.1912

Collins, R., Elliott, S., Adams, R., 2005. Overland flow delivery of faecal bacteria to a headwater pastoral stream. Journal of Applied Microbiology 99, 126-132. doi: 10.1111/j.1365-2672.2005.02580.x

Derrien, M., Jardé, E., Gruau, G., Pierson-Wickmann, A.C., 2011. Extreme variability of steroid profiles in cow feces and pig slurries at the regional scale: implications for the use of steroids to specify fecal pollution sources in waters. Journal of Agricultural and Food Chemistry 59, 7294-7302. doi: 10.1021/jf201040v

Derrien, M., Jardé, E., Gruau, G., Pourcher, A.M., Gourmelon, M., Jadas-Hecart, A., PiersonWickmann, A.C., 2012. Origin of fecal contamination in waters from contrasted areas: stanols as microbial source tracking markers. Water Research 46, 4009-4016. doi: 10.1016/j.watres.2012.05.003

Derrien M., Arcega Cabrera, F., Libertad Velazquez Tavera, N., Kantun Manzano, C.A., Capella Vizcaino, S., 2015. Sources and distribution of organic matter along the Ring of Cenots, Yucatan, Mexico : Sterol markers and statistical approaches. Science of the Total Environment 511, 223-229. doi: 10.1016/j.scitotenv.2014.12.053

Dubreuil, V., Huon, F., Lejeune, C., 1996. Les précipitations intenses en Bretagne. Norois 170, 395-406. 
EU Directive 2006/7/EC of the European Parliament and of the Council of 15 February 2006 concerning the management of bathing water quality and repealing Directive 76/160/EEC. Off. J. Eur. Union 2006, L64, 37-51.

Field, K.G., Samadpour, M., 2007. Fecal source tracking, the indicator paradigm, and managing water quality. Water Research 41, 3517-3538. doi: 10.1016/j.watres.2007.06.056

Heaney, C.D, Myers, K., Wing, S. Hall, D., Baron, D., Stewart, J.R., 2015. Source tracking swine fecal waste in surface water proximal to swine concentrated animal feeding operations. Science of the Total Environment 511, 676-683. doi: 10.1016/j.scitotenv.2014.12.062

Gerard, P., 2014. Metabolism of cholesterol and bile acids by the gut microbiota. Pathogens 3, 14-24. doi:10.3390/pathogens3010014

Gourmelon, M., Caprais, M.P., Mieszkin, S., Marti, R., Wery, N., Jardé, E., Derrien, M., Jadas-Hecart, A., Communal, P.Y., Jaffrezic, A., Pourcher, A.M., 2010. Development of microbial and chemical MST tools to identify the origin of the faecal pollution in bathing and shellfish harvesting waters in France. Water Research 44, 4812-4824. doi: 10.1016/j.watres.2010.07.061

Jeanneau, L., Jardé, E., Gruau, G., 2011. Influence of salinity and natural organic matter on the solid phase extraction of sterols and stanols: Application to the determination of the human sterol fingerprint in aqueous matrices. Journal of Chromatography A, 1218, 25132520. doi : 10.1016/j.chroma.2011.02.066

Jeanneau, L., Solecki, O., Wéry, N., Jardé, E., Gourmelon, M., Communal, P-Y., JadasHécart, A., Caprais, M-P., Gruau G., Pourcher A-M., 2012. Relative decay of fecal indicator bacteria and human-associated markers: a microcosm study simulating wastewater input into seawater and freshwater. Environmental Science and Technology 46, 2375-2382. doi : 10.1021/es203019y

Le Guyader, F.S., Atmar, R.L., Maalouf, H., Le Pendu, J., 2013. Shellfish contamination by norovirus: strain selection based on ligand expression? Clinical virology 41, 3-18.

Leeming, R., Ball, A., Ashbolt, N., Nichols, P., 1996. Using faecal sterols from humans and animals to distinguish faecal pollution in receiving waters. Water Research 30, 2893-2900. doi: 10.1016/S0043-1354(96)00011-5

Liang, L., Goh, S.G., Vergara, G.G., Fang, H.M., Rezaeinejad, S., Chang, S.Y., Bayen, S., Lee, W.A., Sobsey, M.D., Rose, J.B., Gin, K.Y., 2015. Alternative fecal Indicators and their empirical relationships with enteric viruses, Salmonella enterica, and Pseudomonas aeruginosa in surface waters of a tropical urban catchment. Applied and Environmental Microbiology 81, 850-860. doi: 10.1128/AEM.02670-14

Mauffret, A., Caprais, M.P., Gourmelon, M., 2012. Relevance of Bacteroidales and F-Specific RNA bacteriophages for efficient fecal contamination tracking at the level of a catchment in France. Applied and Environmental Microbiology 78, 5143-5152. doi: 10.1128/AEM.0031512

McLellan, S.L., Hollis, E.J., Depas, M.M., Van Dyke, M., Harris, J., Scopel, C.O., 2007. Distribution and fate of Escherichia coli in Lake Michigan following contamination with urban stormwater and combined sewer overflows. Journal of Great Lakes Research 33, 566-580. doi: 10.3394/0380-1330(2007)33[566:DAFOEC]2.0.CO;2 
Mieszkin, S., Furet, J.P., Corthier, G., Gourmelon, M., 2009. Estimation of pig fecal contamination in a river catchment by real-time PCR using two pig-specific Bacteroidales 16S rRNA genetic markers. Applied and Environmental Microbiology 75, 3045-3054. doi: 10.1128/AEM.02343-08

Mieszkin, S., Yala, J.F., Joubrel, R., Gourmelon, M., 2010. Phylogenetic analysis of Bacteroidales 16S rRNA gene sequences from human and animal effluents and assessment of ruminant faecal pollution by real-time PCR. Journal of Applied Microbiology 108, 974-984. doi: 10.1111/j.1365-2672.2009.04499.x.

Mieszkin, S., Caprais, M.P., Le Mennec, C., Le Goff, M., Edge, T., Gourmelon, M., 2013. Identification of the origin of fecal contamination in shellfish and environmental waters from a French estuary using Bacteroidales markers and F-specific RNA bacteriophages. Journal of Applied Microbiology, 115, 897-907. doi: 10.1111/jam.12260

Moatar, F., Abbott, B.W., Minaudo, C., Curie, F., and Pinay, G., 2017. Elemental properties, hydrology, and biology interact to shape concentration-discharge curves for carbon, nutrients, sediment, and major ions. Water Resources Research 53, 1270-1287. doi:10.1002/2016WR019635.

Muirhead, R.W., Collins, R.P., Bremer, P.J., 2005. Erosion and subsequent transport state of Escherichia coli from cowpats. Applied and Environmental Microbiology 71, 2875-2879. doi: 10.1128/AEM.71.6.2875-2879.2005

Muirhead, R.W., Monogan, R.M., 2012. A two-reservoir model to predict Escherichia coli losses to water from pastures grazed by dairy cows. Environmental International 40, 8-14. doi : 10.1016/j.envint.2011.11.009

Ohad, S., Vaizel-Ohayon, D., Rom, M., Guttman, J., Berger, D., Kravitz, V., Pilo, S., Huberman, Z., Kashi, Y., Rorman, E., 2015. Microbial source tracking in adjacent karst springs. Applied Environmental Microbiology 81. 5037-5047. doi:10.1128/AEM.00855-15.

Pommepuy, M., Hervio-Heath, D., Caprais, M.P., Gourmelon, M., Le Saux, J.C., Le Guyader, S., 2005. Fecal contamination in coastal areas: An engineering approach. In: Oceans and health pathogens in the marine environment, Edited by Belkin S., Colwell R.R., Springer, New York, USA, 331-359.

Patris, T., Perenne, N., 2011. Plage de Pen an Traon, Commune de Guipavas, Finistère, Profil des eaux de baignade, Brest métropole océane, décembre 2011. 102p.

Raith, M.R., Kelty, C.A., Griffith, J.F., Schriewer, A., Wuertz, S., Mieszkin, S., Gourmelon, M., Reischer, G., Farnleitner, A.H., Ervin, J., Holden, P., Jay, J.A., Boehm, A.B., Rose, J.B., Meijer, W.G., Sivaganesan, M., Shanks, O.C., 2013. Comparison of PCR-based assays for the characterization of ruminant and cattle fecal pollution. Water Research 47, 6921-6928. doi.org/10.1016/j.watres.2013.03.061

Regulation (EC) \#854/2004 of the European parliament and of the council of 29 April 2004 laying down specific rules for the organization of official controls on products of animal origin intended for human consumption.

Rusinol, M., Moriarty, E., Lin, S., Bofill-Mas, S., Gilpin, B., 2016. Human-, ovine-, bovinespecific viral source tracking tools to discriminate between the major fecal sources in agricultural waters. Food and Environmental Virology, 8, 34-45. doi: 10.1007/s12560-0159223-3 
Seurinck, S., Verstraete, W., Siciliano, S.D., 2005. Microbial source tracking for identification of fecal pollution. Reviews in environmental science and bio/technology, 4, 19-37. doi: $10.1007 / \mathrm{s} 11157-005-4997-7$

Sidhu, J.P.S., Ahmed, W., Gernjak, W., Aryal, R., McCarthy, D., Palmer, A., Kolotelo, P., Toze, S., 2013. Sewage pollution in urban stormwater runoff as evident from the widespread presence of multiple microbial and chemical source tracking markers. Science of The Total Environment 463-464, 488-496. doi : 10.1016/j.scitotenv.2013.06.020

Solecki, O., Jeanneau, L., Jardé, E., Gourmelon, M., Marin, C., Pourcher, A-M., 2011. Persistence of microbial and chemical pig manure markers as compared to faecal indicator bacteria survival in freshwater and seawater microcosms. Water Research, 45, 4623-4633. doi : 10.1016/j.watres.2011.06.012

Soller, J.A., Schoen, M.E., Bartrand, T., Ravenscroft, J.E., Ashbolt, N.J., 2010. Estimated human health risks from exposure to recreational waters impacted by human and non-human sources of faecal contamination. Water Research 44, 4674-4691. doi: 10.1016/j.watres.2010.06.049

Tran, N.H., Gin, K.Y.H., Ngo, H.H., 2015. Fecal pollution source tracking toolbox for identification, evaluation and characterization of fecal contamination in receiving urban surface waters and groundwater. Science of The Total Environment 538, 38-57. doi: 10.1016/j.scitotenv.2015.07.155

Villemur, R., Imbeau, M. Vuong, M.N., Masson, L. Payment, P., 2015. An environmental survey of surface waters using mitochondrial DNA from human, bovine and porcine origin as fecal source tracking markers. Water Research 69, 143-153. doi: 10.1016/j.watres.2014.10.063 


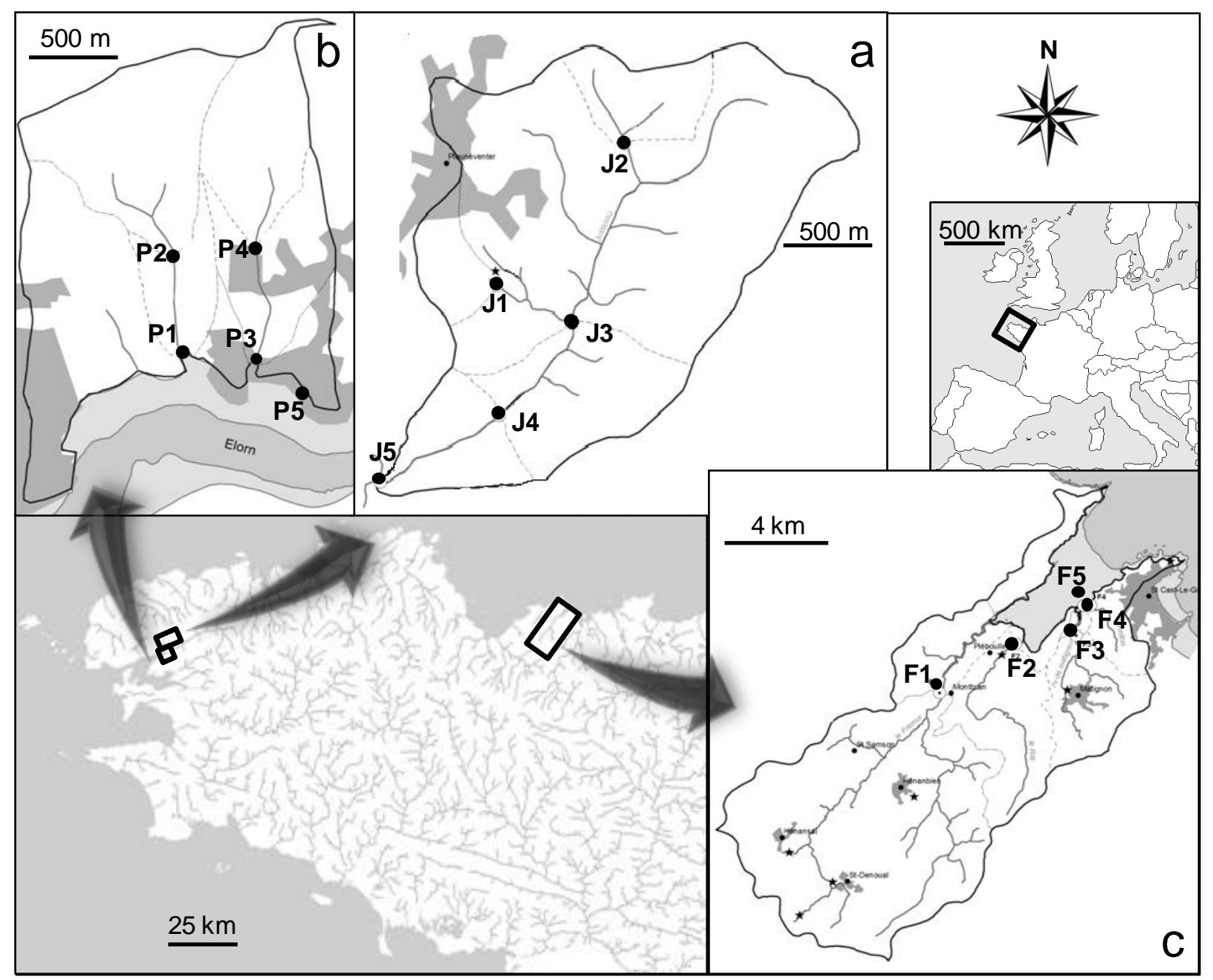

Figure 1. Location of the sampling catchments, sampling points and catchment characteristics at each catchment; (a) Justiçou (catchment J), (b) Pen an Traon (catchment P) and (c) La Fresnaye (catchment F). 

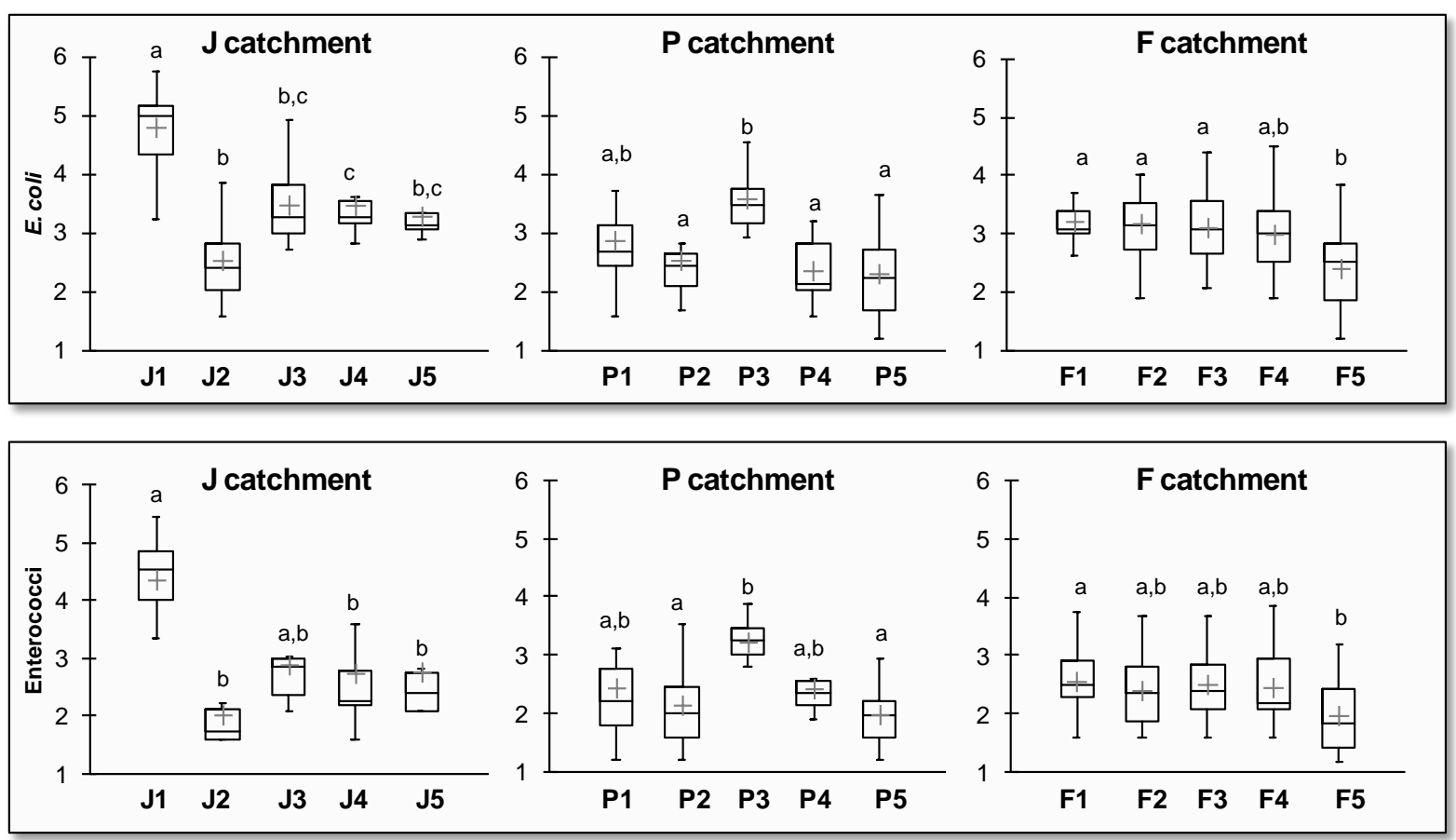

Figure 2. Box plots of E. coli (top) and enterococci (bottom) at the three catchments. Values below the LQ were not considered. The concentrations are expressed in $\log _{10}$ MPN/100 ml.

At each catchment independently, significant difference were tested using pairwise non-parametric Kruskal-Wallis test. Different letters denote significant differences and same letters denote no significant difference. 


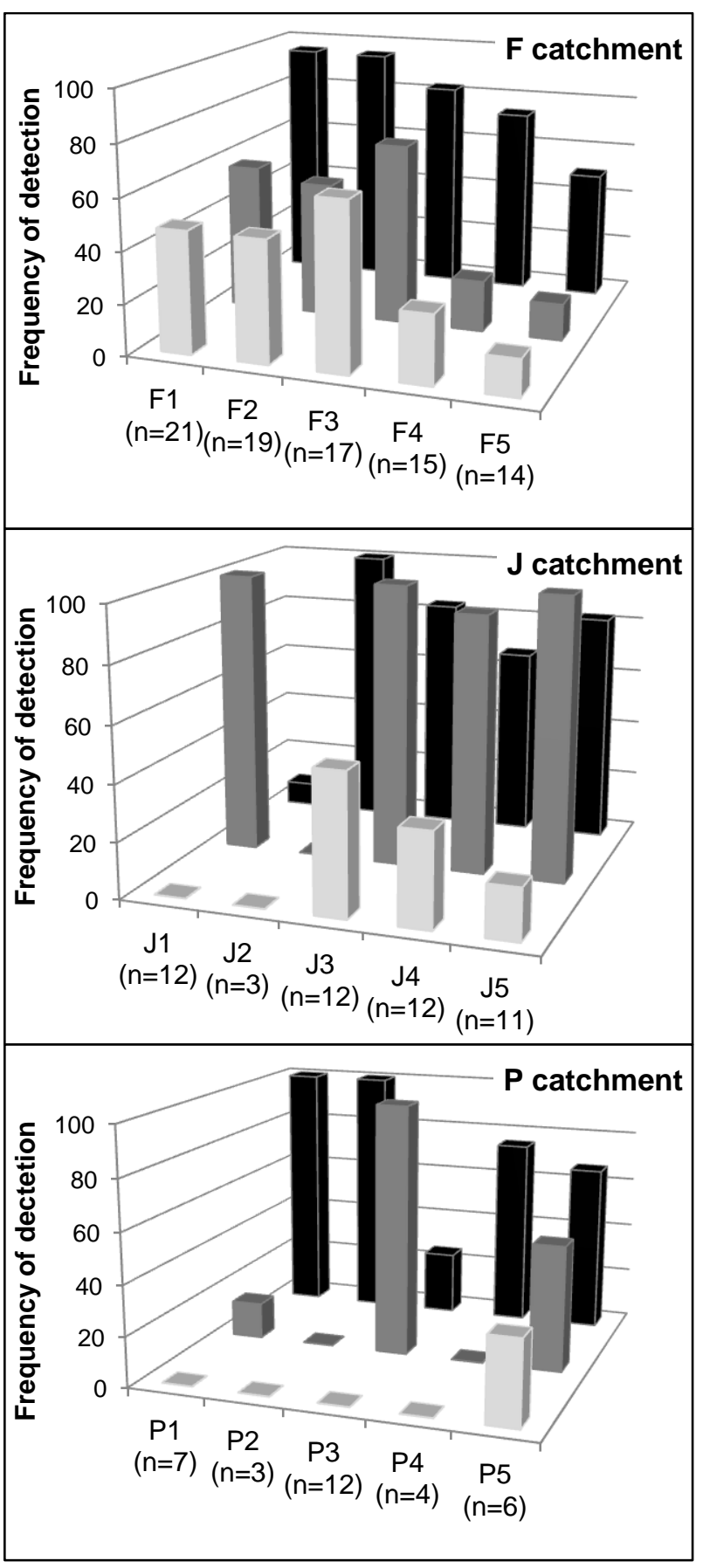

Figure 3. Frequency of detection (in \%) of porcine (light grey), bovine (dark) and human (dark grey) associated-markers in the three catchments. The number in parentheses below the sampling point represents the number of sample size. 


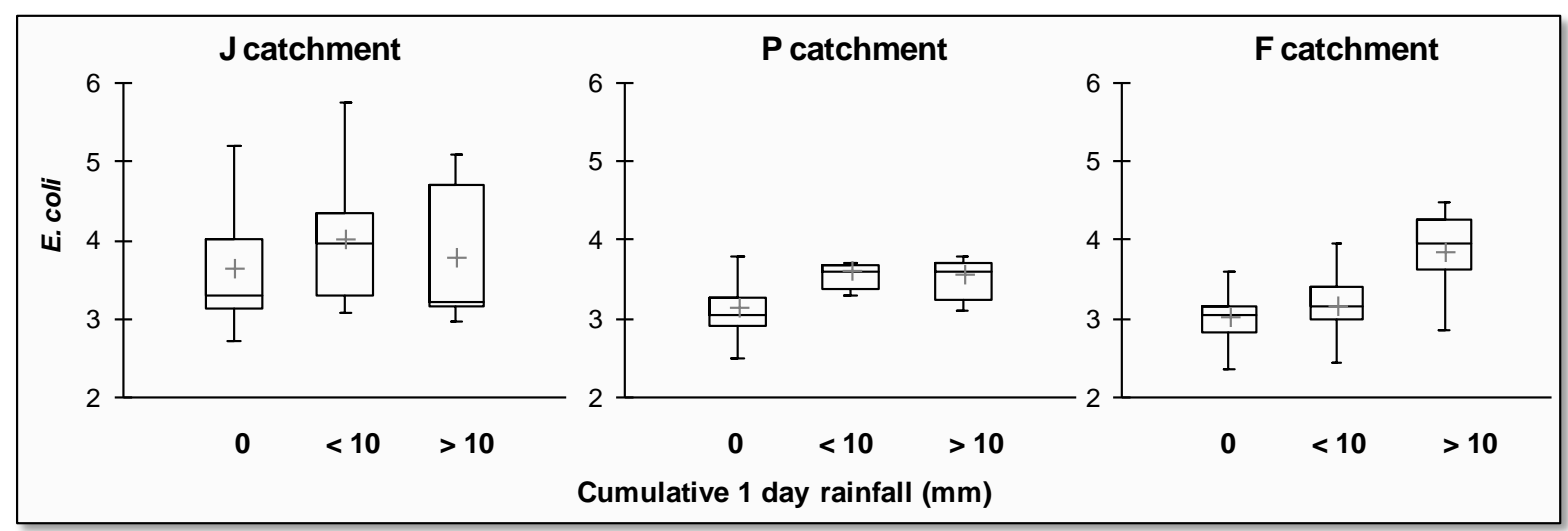

Figure 4. Boxplot of the $E$. coli concentration ( $\log _{10} \mathrm{MPN} / 100 \mathrm{ml}$ ) according to the rainfall intensity (1-day rainfall, in $\mathrm{mm}$ ) in the three catchments. 


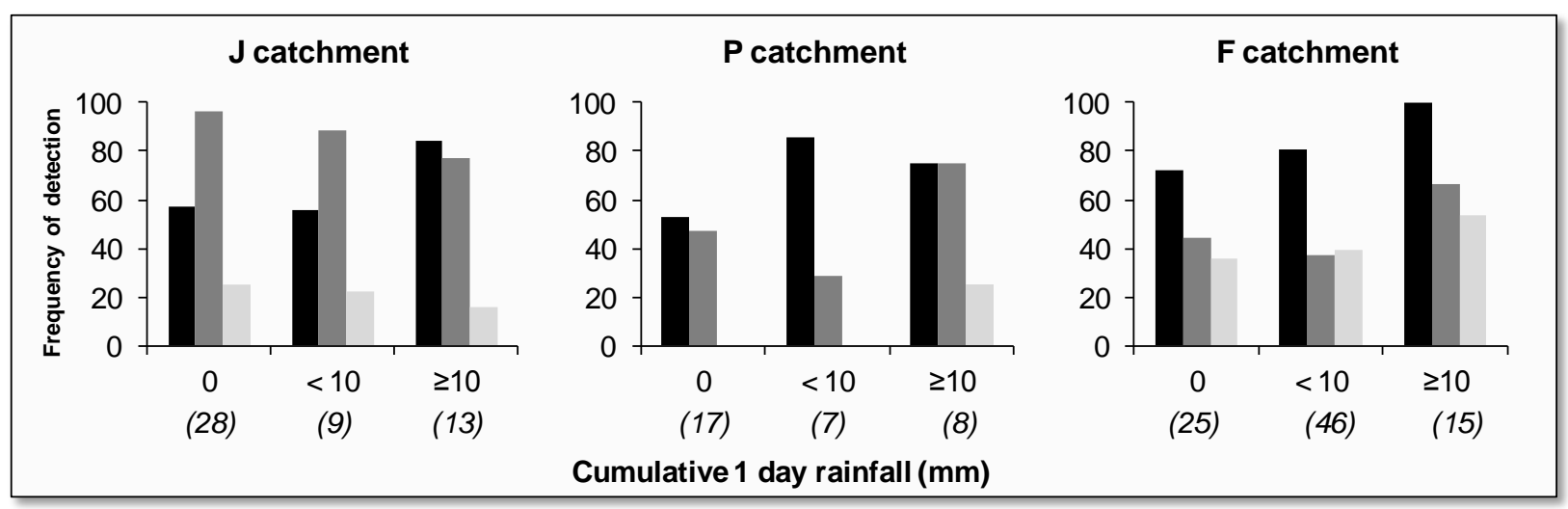

Figure 5. Rainfall effect on the sources of fecal contamination (in frequency of detection -\%) in the three catchments (human markers in dark grey, bovine markers in black and porcine markers in light grey). Numbers in parentheses represent the sample size. 
Table 1. Rainfall and microbial data at the J, P and F catchments. Data below the limit of quantification were not considered.

\begin{tabular}{|c|c|c|c|c|c|c|c|c|c|c|c|c|}
\hline & \multicolumn{4}{|c|}{ J catchment } & \multicolumn{4}{|c|}{$P$ catchment } & \multicolumn{4}{|c|}{ F catchment } \\
\hline & $\mathrm{n}^{\mathrm{a}}$ & $\begin{array}{c}\text { mea } \\
n\end{array}$ & $\min ^{b}$ & $\max ^{c}$ & $\mathrm{n}^{\mathrm{a}}$ & $\begin{array}{c}\text { mea } \\
n\end{array}$ & $\min ^{b}$ & $\max ^{\mathrm{c}}$ & $\mathrm{n}^{\mathrm{a}}$ & $\begin{array}{c}\text { mea } \\
\mathrm{n}\end{array}$ & $\min ^{b}$ & $\max ^{c}$ \\
\hline $\begin{array}{c}\text { E. coli } \\
\log _{10} \mathrm{MPN} / 100 \\
\mathrm{~mL}\end{array}$ & 60 & 3.5 & 1.6 & 5.8 & $\begin{array}{l}5 \\
5\end{array}$ & 2.8 & 1.2 & 4.8 & $\begin{array}{c}11 \\
7\end{array}$ & 3.0 & 1.2 & 5.3 \\
\hline $\begin{array}{c}\text { Enterococci } \\
\log _{10} \mathrm{MPN} / 100 \\
\mathrm{~mL}\end{array}$ & 53 & 3.0 & 1.6 & 6.4 & $\begin{array}{l}4 \\
2\end{array}$ & 2.5 & 1.2 & 4.5 & 98 & 2.4 & 1.2 & 4.8 \\
\hline $\begin{array}{c}\text { HF 183 } \\
\log _{10} \text { copies } / 100 \\
\text { mL }\end{array}$ & 46 & 4.8 & 3.0 & 6.9 & $\begin{array}{l}1 \\
8\end{array}$ & 4.3 & 3.0 & 6.0 & 44 & 3.6 & 2.4 & 6.0 \\
\hline $\begin{array}{c}\text { Rum2Bac } \\
\log _{10} \text { copies } / 100 \\
\text { mL }\end{array}$ & 12 & 3.6 & 2.6 & 4.7 & $\begin{array}{l}2 \\
3\end{array}$ & 4.5 & 3.0 & 5.3 & 90 & 3.6 & 2.0 & 6.7 \\
\hline $\begin{array}{c}\text { Pig2Bac } \\
\log _{10} \text { copies } / 100 \\
\mathrm{~mL} \\
\end{array}$ & 2 & 3.1 & 3.1 & 3.1 & 2 & 3.3 & 2.9 & 3.6 & 36 & 3.1 & 1.8 & 4.8 \\
\hline Stanols $^{d}(\mu \mathrm{g} / \mathrm{L})$ & 57 & 0.73 & 0.03 & 3.85 & $\begin{array}{l}4 \\
2\end{array}$ & 0.82 & 0.07 & $\begin{array}{c}17.9 \\
8\end{array}$ & 74 & 4.37 & 0.08 & $\begin{array}{c}71.8 \\
9\end{array}$ \\
\hline $\begin{array}{l}\text { 1-day rainfall } \\
(\mathrm{mm})\end{array}$ & 25 & 16.3 & 0.2 & 45.8 & $\begin{array}{l}2 \\
5 \\
\end{array}$ & 16.3 & 0.2 & 45.8 & 70 & 5.6 & 0.2 & 20.2 \\
\hline
\end{tabular}

${ }^{a}$ number of individual for each parameter, ${ }^{b}$ minimum value, ${ }^{c}$ maximum value, ${ }^{d}$ Stanols correspond to the sum of the concentrations of the six stanols used in the principal component analysis model. 